\title{
KAJIAN KELAYAKAN TEKNIS DAN FINANSIAL PRODUKSI NUGGET JAMUR TIRAM PUTIH (Pleurotus ostreatus) RASA IKAN TONGKOL (Euthynus aletrates) SKALA INDUSTRI KECIL
}

\author{
Cahyuni Novia \\ STT Nurul Jadid Probolinggo
}

\begin{abstract}
Pleurotus ostreatus with Euthynus aletrates taste was one kind of Pleurotus ostreatus nugget processing which was chopped and added with Euthynus aletrates and various kinds of spices, mixed with blinding agents, formed into certain shapes and subsequently smeared with bread crumb and then freezed.

Randomized Block Design was used as research method, Friedman test was used as organoleptic test, while effectivity index was used to determine the best treatments of chemical and organoleptic parameters. Break Event Point (BEP), Payback Period (PP), Net Present Value (NPV) and Profitability Index (PI) were used in calculating financial feasibility study.

The result research showed the best treatment based on effectivity index was obtained from $100 \mathrm{~g}$ Pleurotus ostreatus, $25 \mathrm{~g}$ Euthynus aletrates and $15 \mathrm{~g}$ wheat flour with following characteristic: fat $0.69 \%$; protein $8.80 \%$; water activity $64.41 \%$; ash $2.26 \%$; carbohydrate $25.94 \%$; taste 6.12 ; colour 4.88 ; and flavour 3.76 . The feasibility analysis result in small scale industry showed the cost of goods manufactured was Rp. $5,695 / 250 \mathrm{~g}$. Break Event Point (BEP) was reached at sales volume of 23,729 unit or Rp. 202,697,442.09. Payback Period was reached at 2 year 8 months 23 days time. Net Present Value (NPV) was Rp. 180,633,576. While the Profitability Index (PI) was 1.46 thereby this industry of nugget production from Pleurotus ostreatus with Euthynus aletrates addition was feasible.
\end{abstract}

Key word : Nugget, Pleurotus ostreatus, Small Scale Industry 
Jamur merupakan bahan pangan yang mulai banyak diminati oleh masyarakat. Disamping harganya yang murah juga kandungan gizinya tinggi. Jamur mempunyai sekitar 45 ribu jenis jamur, sebanyak 2000 jenis dapat dimakan, diantaranya sekitar 25 jenis digunakan secara luas sebagai bahan pangan. Di Indonesia, jenis jenis jamur banyak dibudidayakan untuk bahan pangan antara lain jamur tiram putih, jamur kuping, jamur champignon, jamur merang dan jamur mutiara (Anonymous, 2008). Saat ini jamur tiram putih adalah jamur komersial yang diproduksi terbesar ke tiga di dunia (Obodai et al, 2003).

Salah satu jenis jamur yang bisa dibuat sebagai makanan siap saji yaitu jamur tiram putih. Hal ini juga didukung oleh mulai makin berkembangnya budi daya jamur tiram di masyarakat dan harganya juga murah (Anonymous, 2008). Salah satu produsen jamur tiram putih di Malang Raya (Batu) dapat memproduksi sekitar $50-200 \mathrm{~kg} /$ hari yang dihasilkan dari 40.000 baglog (Satriyanto,2009).

Nugget jamur (mushroom nugget) merupakan salah satu jenis makanan baru, dibuat dari jamur tiram putih dengan penambahan bumbu-bumbu dan dicetak, kemudian dilumuri dengan pelapis (coating dan breading) yang dilanjutkan dengan penggorengan. Pada dasarnya nugget jamur sama dengan nugget ayam atau nugget ikan, perbedaannya terletak pada bahan baku yang digunakan.

Jamur tiram putih dapat digunakan sebagai alternatif bahan baku pembuatan nugget karena tekstur jamur tiram yang mirip dengan daging ayam. Secara statistik jamur tiram sangat menjanjikan, karena bisa menurunkan kadar kolesterol hingga 12,6 persen dan trigliserol turun hingga 27,2 persen (Bobek et al.,1995). Jamur tiram juga mempunyai efek antioksidan dengan turunnya peroksidasi di dalam eritrosit (Bobek et al.,1998).

Pembuatan nugget jamur tiram putih juga dapat dikombinasikan dengan ikan, salah satunya ikan tongkol. Ikan tongkol merupakan salah satu hasil perikanan air laut yang tidak asing lagi bagi masyarakat Indonesia. Ikan tongkol memiliki kandungan gizi yang sangat tinggi, rasanya lezat, dagingnya padat dan lembut, disamping itu harganya yang relatif lebih murah (Utomo dkk., 2004). Penambahan ikan tongkol pada nugget jamur tiram putih 
diharapkan dapat meningkatkan nilai gizi dari nugget tersebut.

Bahan pengikat menjadi komponen penting dalam pembuatan nugget, sehingga dalam pembuatan nugget ditambahkan tepung yang berfungsi sebagai bahan pengikat. Bahan pengikat pada pembuatan nugget berguna untuk memperbaiki cita rasa, meningkatkan daya ikat air, menurunkan peyusutan akibat pemasakan, memberi warna yang terang, membentuk tekstur yang padat, menghemat biaya produksi dan memperbaiki elastisitas produk (Tanikawa, 1998).

Menurut hasil penelitian yang dilakukan oleh Suharyono $d k k$. (2006), bahwa nugget tempe kedelai dengan menggunakan tepung maizena $15 \%$ sebagai bahan pengikat memiliki kemiripan dengan produk komersial dan sangat disukai oleh panelis. Sedangkan hasil uji fisik penelitian yang dilakukan oleh Surjoseputro dkk. (2004) terhadap nugget babi dengan menggunakan $4 \%$ tepung kedelai dan $6 \%$ tepung maizena adalah yang paling terbaik dan disukai oleh panelis.

Berdasarkan uraian diatas, perlu kiranya diadakan penelitian tentang pembuatan nugget jamur tiram putih dengan atau tanpa ditambahkan ikan tongkol sebagai salah satu alternatif pembuatan nugget dengan menggunakan bahan pengikat tepung sagu, maizena dan tepung terigu yang berkualitas dan layak secara teknis dan finansial.

\section{METODE PENELITIAN \\ Tempat dan Waktu}

Penelitian dilakukan di Laboratorium Teknologi Hasil Pertanian,UniversitasMuhammadi yah Malang. Waktu penelitian dari bulan Mei - Juni 2010.

\section{Penelitian Tahap I : Pengaruh} Jenis Tepung Terhadap Nugget Jamur tiram Putih

Dalam percobaan ini digunakan Rancangan Acak Kelompok (RAK) Faktorial. Terdiri dari dua faktor, dimana faktor pertama terdiri dari dua level, dan faktor kedua terdiri dari tiga level.

Kombinasi perlakuan terbaik diperoleh dari indeks efektifitas berdasarkan parameter kimia (kadar Air, Lemak, Protein, Abu, Karbohidrat) dan parameter uji organoleptik (warna, rasa dan aroma). Sedangkan uji organoleptik menggunakan uji Friedman. Selanjutnya kombinasi perlakuan terbaik akan dilakukan perbandingan dengan produk nugget yang sudah beredar dipasar. 
Pada tahap ini produk nugget jamur tiram putih akan dibandingkan dengan chicken nugget merk So Good dan Charm. Parameter perbandingan menggunakan uji organoleptik (warna, rasa dan aroma).

\section{Penelitian Tahap II: Scale Up (Penggandaan Skala)}

Penelitian Tahap II ini akan dilakukan penggandaan skala (scale up) pada kombinasi perlakuan terbaik tahap I sebanyak $20 \mathrm{~kg}$, kemudian akan diamati parameter kimianya agar tidak berbeda jauh dengan kombinasi perlakuan terbaik tahap I. Parameter kimia pada scale up $20 \mathrm{~kg}$ meliputi kadar air, lemak, protein, abu dan karbohidrat.. Penelitian ini terkait pada peningkatan volume jamur tiram putih dan bahan pembantu lainnya, serta penyesuaian peralatan yang mendekati sektor industri berskala kecil.

Penelitian Tahap III : Kajian Kelayakan Finansial Produk Nugget Jamur Tiram Putih Skala Industri Kecil
Pada tahap III akan dilakukan kajian kelayakan finansial produk nugget pada skala industri kecil berdasarkan

perlakuan terbaik tahap I. Adapun perhitungan kelayakan finansial nugget skala industri kecil meliputi perhitungan Break Event Point (BEP), Net Present Value (NPV), Profitability Index (PI), dan Payback Periods (PP).

\section{Teknik Pengumpulan Data}

Untuk menganalisis dan menginterpretasikan data dengan baik, maka diperlukan data yang akurat dan sistematis agar hasil yang didapat mampu menggambarkan situasi obyek yang diteliti dengan benar. Data tersebut bersumber dari dua data yaitu, data primer dan sekunder.

\section{HASIL DAN PEMBAHASAN}

\section{Penelitian Tahap I : Pengaruh Jenis Tepung Terhadap Nugget Jamur tiram Putih}

\section{Kadar Lemak}

Rerata kadar lemak pada berbagai kombinasi perlakuan antara jamur tiram putih yang ditambahkan ikan tongkol dan tanpa ikan tongkol dengan berbagai jenis tepung berkisar antara 0,69$2,73 \%$. 
Tabel 1. Rerata Kadar Lemak (\%) pada Berbagai Kombinasi Perlakuan

\begin{tabular}{|c|c|c|}
\hline $\begin{array}{c}\text { Kombinasi } \\
\text { Perlakuan }\end{array}$ & $\begin{array}{c}\text { Rerata } \\
\text { Kadar } \\
\text { Lemak (\%) }\end{array}$ & $\begin{array}{c}\text { DMRT } \\
(\boldsymbol{\alpha}=\mathbf{0 , 0 1})\end{array}$ \\
\hline A1B1 & $2,03 \mathrm{~d}$ & 0,02 \\
\hline $\mathrm{A} 1 \mathrm{~B} 2$ & $2,73 \mathrm{f}$ & 0,02 \\
\hline $\mathrm{A} 1 \mathrm{~B} 3$ & $2,47 \mathrm{e}$ & 0,02 \\
\hline $\mathrm{A} 2 \mathrm{~B} 1$ & $1,33 \mathrm{c}$ & 0,02 \\
\hline $\mathrm{A} 2 \mathrm{~B} 2$ & $0,69 \mathrm{a}$ & 0,02 \\
\hline $\mathrm{A} 2 \mathrm{~B} 3$ & $1,08 \mathrm{~b}$ & 0,02 \\
\hline
\end{tabular}

Keterangan : Angka rerata yang diikuti dengan huruf yang sama pada kolom yang sama tidak berbeda nyata pada uji Duncan 1\%

Tabel 1 menyajikan uji DMRT $(\alpha=0,01)$ kombinasi perlakuan terbaik kadar lemak diperoleh dari jamur tiram putih $100 \mathrm{~g}$, tepung terigu $15 \mathrm{~g}$ dan ikan tongkol $25 \mathrm{~g}$ sebesar $0,69 \%$ dan sangat berbeda nyata dengan yang lain.

Gambar 1 menyajikan bahwa kadar lemak tertinggi diperoleh pada kombinasi perlakuan jamur tiram putih $100 \mathrm{~g}$ dan tepung terigu $15 \mathrm{~g}$ sebesar $2,73 \%$ dan terendah pada jamur tiram putih $100 \mathrm{~g}$, ikan tongkol $25 \mathrm{~g}$ dan tepung terigu $15 \mathrm{~g}$ sebesar $0,69 \%$.

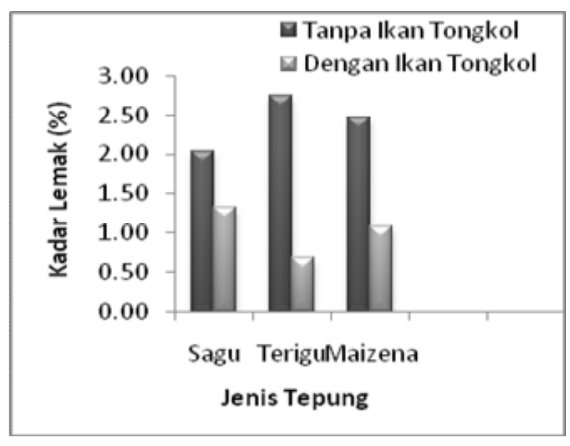

Gambar 1. Grafik Rerata Kadar Lemak (\%) pada Berbagai Kombinasi Perlakuan

Kadar lemak nugget jamur dalam penelitian ini sangat rendah jika dibandingkan dengan produk sejenis (chicken nugget). Sedangkan kadar lemak chicken nugget sesuai standar SNI maksimal sebesar 20\%. Menurut Syartiwidya (2003) menyatakan bahwa pada nugget ikan yang disimpan beku, perubahan mikrostruktur yang terjadi selama penyimpanan terlihat ronggarongga sebagian membentuk parit atau saluran, sehingga air atau lemak akan mudah mengalir keluar nugget saat thawing.

\section{Kadar Protein}

Rerata kadar protein pada berbagai kombinasi perlakuan antara jamur tiram putih yang ditambahkan ikan tongkol dan 
tanpa ikan tongkol dengan berbagai jenis tepung berkisar antara 5,13 $8,80 \%$. Rerata nilai kadar protein pada berbagai kombinasi perlakuan ditunjukkan pada Tabel 2.

Tabel 2 menyajikan uji DMRT ( $\alpha=0,01)$ kombinasi perlakuan terbaik kadar protein diperoleh dari jamur tiram putih $100 \mathrm{~g}$, ikan tongkol $25 \mathrm{~g}$ dan tepung terigu $15 \mathrm{~g}$ sebesar $8,80 \%$ dan sangat berbeda nyata dengan yang lain

Tabel 2. Rerata Kadar Protein (\%) pada Berbagai Kombinasi Perlakuan

\begin{tabular}{|c|c|c|}
\hline $\begin{array}{c}\text { Kombinasi } \\
\text { Perlakuan }\end{array}$ & $\begin{array}{c}\text { Rerata } \\
\text { Kadar } \\
\text { Protein }(\boldsymbol{\%})\end{array}$ & $\begin{array}{c}\text { DMRT } \\
(\boldsymbol{\alpha = 0 , 0 1})\end{array}$ \\
\hline A1B1 & $5,84 \mathrm{~b}$ & 0,05 \\
\hline A1B2 & $7,63 \mathrm{c}$ & 0,05 \\
\hline A1B3 & $5,13 \mathrm{a}$ & 0,05 \\
\hline A2B1 & $8,63 \mathrm{~d}$ & 0,05 \\
\hline A2B2 & $8,80 \mathrm{f}$ & 0,05 \\
\hline A2B3 & $8,75 \mathrm{e}$ & 0,05 \\
\hline
\end{tabular}

Keterangan : Angka rerata yang diikuti dengan huruf yang sama pada kolom yang sama tidak berbeda nyata pada uji Duncan $1 \%$

Gambar 2 menyajikan bahwa kadar protein tertinggi diperoleh pada kombinasi perlakuan jamur tiram putih $100 \mathrm{~g}$, ikan tongkol $25 \mathrm{~g}$ dan tepung terigu $15 \mathrm{~g}$ sebesar $8,80 \%$ dan terendah pada jamur tiram putih $100 \mathrm{~g}$ dan tepung maizena $15 \mathrm{~g}$ sebesar 5,13\%.

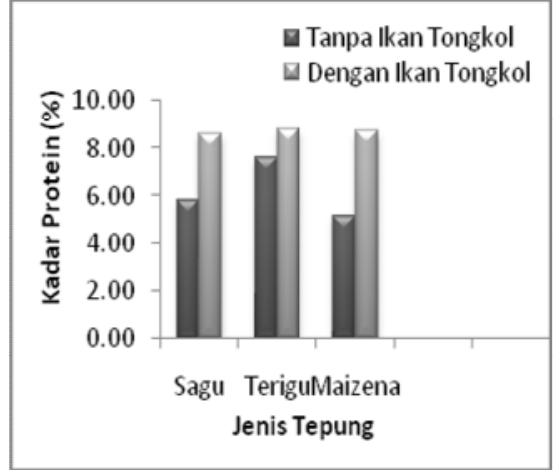

Gambar 2. Grafik Rerata Kadar Protein (\%) pada Berbagai Kombinasi Perlakuan

Dari hasil analisis diperoleh bahwa kadar protein nugget jamur tiram putih dengan penambahan ikan tongkol mengalami kenaikan walaupun masih dibawah standar yang ditetapkan SNI untuk chicken nugget minimal sebesar 12\%, Sedangkan kandungan protein ikan tongkol segar sebesar 48,38\%. Penurunan kadar protein selama penyimpanan beku pada nugget diduga karena adanya denaturasi protein. Karena pada nugget pengamatan tidak memakai anti denaturasi pada pembuatannya, sehingga saat pembekuan terjadi denaturasi protein. Connell (1980) menyatakan bahwa proses pembekuan cenderung menyebabkan susunan makanan berubah dan perubahan ini akan 
langsung berakibat pada susunan proteinnya.

\section{Kadar Air}

Rerata kadar air pada berbagai kombinasi perlakuan antara jamur tiram putih yang ditambahkan ikan tongkol dan tanpa ikan tongkol dengan berbagai jenis tepung berkisar $61,12-64,41 \%$.

Tabel 3. Rerata Kadar Air (\%) pada Berbagai Kombinasi Perlakuan

\begin{tabular}{|c|c|c|}
\hline $\begin{array}{c}\text { Kombinasi } \\
\text { Perlakuan }\end{array}$ & $\begin{array}{c}\text { Rerata } \\
\text { Kadar Air } \\
(\mathbf{\%})\end{array}$ & $\begin{array}{c}\text { DMRT } \\
(\boldsymbol{\alpha}=\mathbf{0 , 0 1})\end{array}$ \\
\hline A1B1 & $61,23 \mathrm{~b}$ & 0,03 \\
\hline A1B2 & $61,12 \mathrm{a}$ & 0,03 \\
\hline A1B3 & $62,82 \mathrm{~d}$ & 0,03 \\
\hline A2B1 & $61,43 \mathrm{c}$ & 0,03 \\
\hline A2B2 & $64,41 \mathrm{f}$ & 0,03 \\
\hline A2B3 & $64,03 \mathrm{e}$ & 0,03 \\
\hline
\end{tabular}

Keterangan : Angka rerata yang diikuti dengan huruf yang sama pada kolom yang sama tidak berbeda nyata pada uji Duncan $1 \%$

Tabel 3 menyajikan uji DMRT $(\alpha=0,01)$ kombinasi perlakuan terbaik kadar air diperoleh dari jamur tiram putih $100 \mathrm{~g}$ dan tepung terigu $15 \mathrm{~g}$ sebesar $61,12 \%$ dan sangat berbeda nyata dengan yang lain.

Gambar 3 menyajikan kadar air tertinggi diperoleh pada jamur tiram putih $100 \mathrm{~g}$, ikan tongkol $25 \mathrm{~g}$ dan tepung terigu $15 \mathrm{~g}$ sebesar $64,41 \%$ dan terendah pada jamur tiram putih $100 \mathrm{~g}$ dan tepung terigu $15 \mathrm{~g}$ sebesar $61,12 \%$. Hal ini disebabkan karena ikan dan jamur mempunyai kadar air yang cukup tinggi. Kadar air ini masih mendekati standar yang ditetapkan oleh SNI untuk kadar air produk chicken nugget yaitu maksimal sebesar $60 \%$.

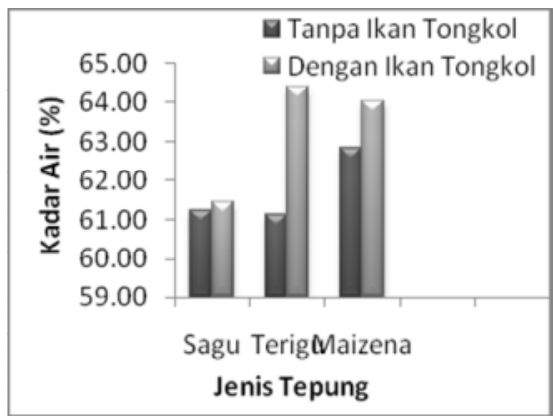

Gambar 3. Grafik rerata Kadar Air (\%) pada Berbagai Kombinasi Perlakuan

\section{Kadar Karbohidrat}

Rerata kadar karbohidrat pada berbagai kombinasi perlakuan antara jamur tiram putih yang ditambahkan ikan tongkol dan tanpa ikan tongkol dengan berbagai jenis tepung berkisar antara 23,99 $29,23 \%$. 
Tabel 4. Rerata Kadar Karbohidrat (\%) pada Berbagai Kombinasi Perlakuan

\begin{tabular}{|c|c|c|}
\hline $\begin{array}{c}\text { Kombinasi } \\
\text { Perlakuan }\end{array}$ & $\begin{array}{c}\text { Rerata Kadar } \\
\text { KH }(\boldsymbol{\%})\end{array}$ & $\begin{array}{c}\text { DMRT } \\
(\boldsymbol{\alpha = 0 , 0 1})\end{array}$ \\
\hline A1B1 & $29,23 \mathrm{f}$ & 0,06 \\
\hline A1B2 & $26,35 \mathrm{e}$ & 0,06 \\
\hline A1B3 & $26,27 \mathrm{~d}$ & 0,06 \\
\hline A2B1 & $25,55 \mathrm{~b}$ & 0,06 \\
\hline A2B2 & $25,94 \mathrm{c}$ & 0,06 \\
\hline A2B3 & $23,99 \mathrm{a}$ & 0,06 \\
\hline
\end{tabular}

Keterangan : Angka rerata yang diikuti dengan huruf yang sama pada kolom yang sama tidak berbeda nyata pada uji Duncan $1 \%$

Gambar 4 menyajikan bahwa kadar karbohidrat tertinggi diperoleh pada kombinasi perlakuan jamur tiram putih $100 \mathrm{~g}$ dan tepung sagu $15 \mathrm{~g}$ sebesar $29,23 \%$ dan terendah pada jamur tiram putih $100 \mathrm{~g}$, tepung maizena $15 \mathrm{~g}$ dan ikan tongkol $25 \mathrm{~g}$ sebesar $23,99 \%$. Hal ini disebabkan karena karbohidrat tepung sagu lebih tinggi dibandingkan dengan tepung terigu dan maizena. Kandungan kadar karbohidrat nugget jamur tiram putih masih mendekati standar yang telah ditetapkan oleh SNI untuk produk chicken nugget, yaitu maksimal sebesar $25 \%$.

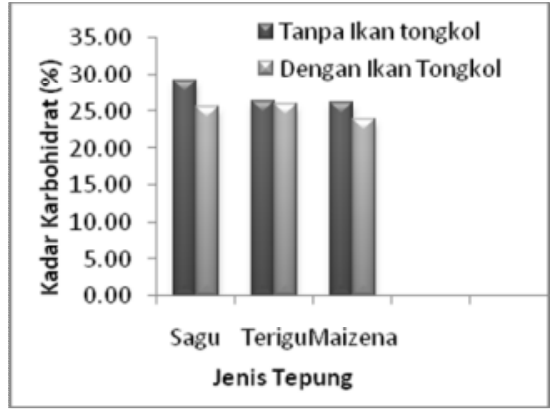

Gambar 4. Grafik Rerata Kadar Karbohidrat (\%) pada Berbagai Kombinasi Perlakuan

\section{Kadar Abu}

Rerata kadar abu pada berbagai kombinasi perlakuan antara jamur tiram putih yang ditambahkan ikan tongkol dan tanpa ikan tongkol dengan berbagai jenis tepung berkisar antara 1,60-2,43\%.

Tabel 5 menyajikan uji DMRT $(\alpha=0,01)$ kombinasi perlakuan terbaik kadar abu diperoleh dari jamur tiram putih $100 \mathrm{~g}$, ikan tongkol $25 \mathrm{~g}$ dan tepung sagu $15 \mathrm{~g}$ sebesar $2,43 \%$ dan sangat berbeda nyata dengan yang lain. 
Tabel 5. Rerata Kadar Abu (\%) Berbagai Kombinasi Perlakuan

\begin{tabular}{|c|c|c|}
\hline $\begin{array}{c}\text { Kombinasi } \\
\text { Perlakuan }\end{array}$ & $\begin{array}{c}\text { Rerata } \\
\text { Kadar Abu } \\
(\boldsymbol{\%})\end{array}$ & $\begin{array}{c}\text { DMRT } \\
(\boldsymbol{\alpha = 0 , 0 1 )}\end{array}$ \\
\hline A1B1 & $1.83 \mathrm{c}$ & 0.01 \\
\hline A1B2 & $1.80 \mathrm{~b}$ & 0.01 \\
\hline A1B3 & $1.60 \mathrm{a}$ & 0.01 \\
\hline A2B1 & $2.43 \mathrm{f}$ & 0.01 \\
\hline A2B2 & $2.26 \mathrm{e}$ & 0.01 \\
\hline A2B3 & $2.13 \mathrm{~d}$ & 0.01 \\
\hline
\end{tabular}

Keterangan : Angka rerata yang diikuti dengan huruf yang sama pada kolom yang sama tidak berbeda nyata pada uji Duncan $1 \%$

Gambar 5 menyajikan bahwa kadar abu tertinggi diperoleh pada kombinasi perlakuan jamur tiram putih $100 \mathrm{~g}$, tepung sagu $15 \mathrm{~g}$ dan ikan tongkol $25 \mathrm{~g}$ sebesar 2,43\% dan terendah pada jamur tiram putih $100 \mathrm{~g}$ dan tepung maizena 15 g sebesar $1,60 \%$.

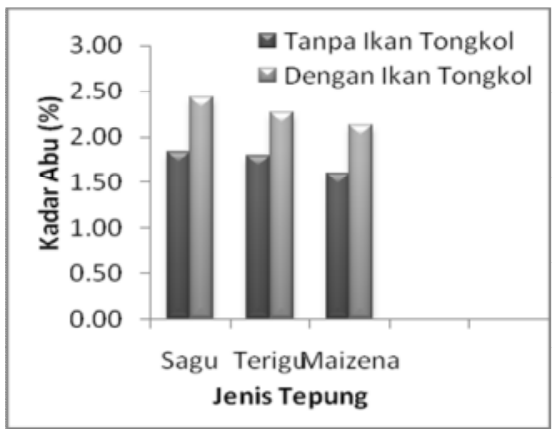

Gambar 5. Grafik rerata Kadar Abu (\%) pada Berbagai Kombinasi Perlakuan

Kadar abu menggambarkan banyaknya mineral yang tidak terbakar menjadi zat yang menguap. Besarnya kadar abu pada produk nugget, diduga karena bahan baku yang digunakan adalah bahan pangan hewani yang cukup tinggi kandungan abunya. Sudarmaji et al (1989) menyatakan bahwa makanan yang berasal dari hewani mengandung kadar abu yang tinggi, hal ini disebabkan oleh kandungan beberapa mineral seperti kalsium, besi dan fosfor.

\section{Pemilihan Perlakuan Terbaik Parameter Kimia}

Penentuan kombinasi perlakuan terbaik jamur tiram putih yang ditambahkan ikan tongkol dan tanpa ikan tongkol dengan berbagai jenis tepung pada penelitian parameter kimia dilakukan dengan menggunakan metode indeks efektivitas (Susrini, 2005). Penilaian perlakuan terbaik disajikan pada Tabel 6. 
Tabel 6. Penilaian Perlakuan Terbaik terhadap Parameter Kimia

\begin{tabular}{|c|c|}
\hline $\begin{array}{c}\text { Kombinasi } \\
\text { Perlakuan }\end{array}$ & Nilai Produk \\
\hline A1B1 & 0,34 \\
\hline A1B2 & 0,57 \\
\hline A1B3 & 0,40 \\
\hline A2B1 & 0,55 \\
\hline A2B2 & $\mathbf{0 , 6 0 *}$ \\
\hline A2B3 & 0,57 \\
\hline
\end{tabular}

* = perlakuan terbaik

Hasil perhitungan menyajikan kombinasi perlakuan terbaik (Tabel 6) pada parameter kimia antara jamur tiram putih yang ditambahkan ikan tongkol dan tanpa ikan tongkol dengan berbagai jenis tepung diperoleh dari kombinasi perlakuan jamur tiram putih $100 \mathrm{~g}$, ikan tongkol $25 \mathrm{~g}$ dan tepung terigu $15 \mathrm{~g}$ dengan karakteristik sebagai berikut: kadar lemak $0,69 \%$; kadar protein $8,80 \%$; kadar air 64,41\%: kadar abu 2,26\% dan kadar karbohidrat 25,94\%.

\section{Uji Organoleptik}

\section{Rasa}

Hasil uji organoleptik menyajikan bahwa rerata ranking kesukaan panelis terhadap rasa dari kombinasi perlakuan antara jamur tiram putih yang ditambahkan ikan tongkol dan tanpa ikan tongkol dengan berbagai jenis tepung berkisar antara 3,64-6,12.

Gambar 6 menyajikan rerata nilai kesukaan panelis terhadap rasa pada berbagai kombinasi perlakuan mempunyai nilai terendah sebesar 3,64 dari kombinasi perlakuan jamur tiram putih $100 \mathrm{~g}$, ikan tongkol $25 \mathrm{~g}$ dan tepung sagu $15 \mathrm{~g}$. Sedangkan nilai tertinggi sebesar 6,12 didapatkan dari kombinasi perlakuan jamur tiram putih $100 \mathrm{~g}$, ikan tongkol $25 \mathrm{~g}$ dan tepung terigu $15 \mathrm{~g}$. Hal ini disebabkan karena dengan pemakaian tepung terigu dan penambahan ikan tongkol menurut kebanyakan panelis terasa ikannya dan lebih lembut.

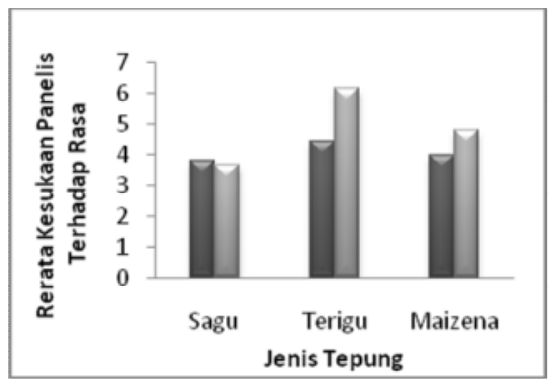

Gambar 6. Rerata Kesukaan Panelis terhadap Rasa

\section{Warna}

Hasil uji organoleptik menyajikan bahwa rerata ranking 
kesukaan panelis terhadap warna dari kombinasi perlakuan antara jamur tiram putih yang ditambahkan ikan tongkol dan tanpa ikan tongkol dengan berbagai jenis tepung berkisar antara 3,72 6,24 .

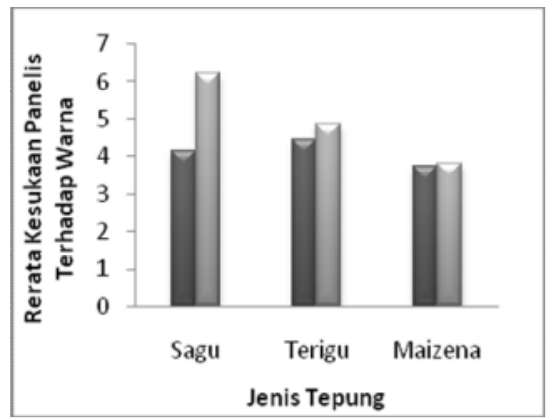

\section{Gambar 7. Rerata Kesukaan Panelis terhadap Warna}

Gambar 7 menyajikan rerata nilai kesukaan panelis terhadap warna pada berbagai kombinasi perlakuan mempunyai nilai terendah sebesar 3,72 dari kombinasi perlakuan jamur tiram putih $100 \mathrm{~g}$ dan tepung maizena 15 g. Sedangkan nilai tertinggi sebesar 6,24 didapatkan dari kombinasi perlakuan jamur tiram putih $100 \mathrm{~g}$, ikan tongkol $25 \mathrm{~g}$ dan tepung sagu 15 g. Hal ini disebabkan karena tepung roti pada balutan luar nugget jamur tiram putih lebih kuat menempel pada nugget jamur tiram putih yang menggunakan tepung sagu.

\section{Aroma}

Hasil uji organoleptik menyajikan bahwa rerata ranking kesukaan panelis terhadap aroma dari kombinasi perlakuan antara jamur tiram putih yang ditambahkan ikan tongkol dan tanpa ikan tongkol dengan berbagai jenis tepung berkisar antara 3,44 6,08 .

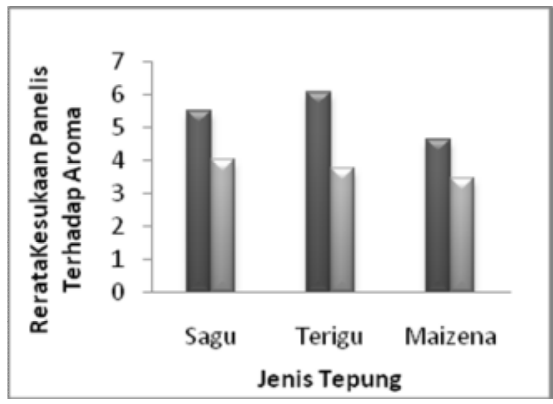

\section{Gambar 8. Rerata Kesukaan Panelis terhadap Aroma}

Gambar 8 menyajikan rerata nilai kesukaan panelis terhadap aroma pada berbagai kombinasi perlakuan mempunyai nilai terendah sebesar 3,44 dari kombinasi perlakuan jamur tiram putih $100 \mathrm{~g}$, ikan tongkol $15 \mathrm{~g}$ dan tepung maizena $15 \mathrm{~g}$. Sedangkan nilai tertinggi sebesar 6,08 didapatkan dari kombinasi 
perlakuan jamur tiram putih $100 \mathrm{~g}$ dan tepung terigu $15 \mathrm{~g}$. Turunnya respon panelis terhadap aroma nugget jamur tiram putih yang menggunakan ikan tongkol, karena terasa ada bau amis ikan.

Pemilihan Perlakuan Terbaik Parameter Organoleptik

Penentuan perlakuan terbaik parameter organoleptik meliputi; rasa, warna dan aroma. Penilaian perlakuan terbaik disajikan pada Tabel 7.

Tabel 7. Perlakuan terbaik Uji Organoleptik

\begin{tabular}{|l|l|}
\hline $\begin{array}{l}\text { Kombinasi } \\
\text { Perlakuan }\end{array}$ & Nilai Produk \\
\hline A1B1 & 0,26 \\
\hline A1B2 & 0,46 \\
\hline A1B3 & 0,16 \\
\hline A2B1 & 0,38 \\
\hline A2B2 & $\mathbf{0 , 6 3} *$ \\
\hline A2B3 & 0,22 \\
\hline
\end{tabular}

* = perlakuan terbaik

Hasil perhitungan menyajikan kombinasi perlakuan terbaik diperoleh dari kombinasi perlakuan jamur tiram putih $100 \mathrm{~g}$, ikan tongkol $25 \mathrm{~g}$ dan tepung terigu $15 \mathrm{~g}$ dengan karakteristik sebagai berikut: rerata kesukaan panelis terhadap rasa 6,12 ; warna 4,88 dan aroma 3,76.
Selanjutnya hasil penelitian tahap I pada skala laboratorium yang kombinasil terbaik akan dilakukan perbandingan dengan produk nugget yang sudah beredar dipasar. Pada tahap ini produk nugget jamur tiram putih akan dibandingkan dengan chicken nugget merk So Good dan Charm.

\section{Rasa}

Hasil uji organoleptik menyajikan bahwa rerata ranking kesukaan panelis terhadap rasa dari kombinasi perlakuan antara Mush Nugget dengan So Good dan Charm berkisar antara 5,55 - 7,2. Rerata ranking tingkat kesukaan panelis terhadap rasa ditunjukkan pada Gambar 9.

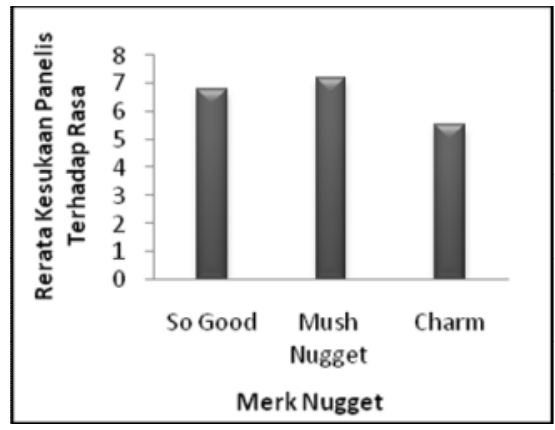

Gambar 9. Rerata Kesukaan Panelis terhadap Rasa

Gambar 9 menyajikan rerata nilai kesukaan panelis terhadap 
rasa pada berbagai merk nugget mempunyai nilai terendah sebesar 5,55 dari merk Charm. Sedangkan nilai tertinggi sebesar 7,2 didapatkan dari merk Mush Nugget. Kebanyakan panelis berpendapat bahwa rasa dari Mush Nugget tidak terlalu gurih yang berasal dari pemakaian MSG yang berlebihan dan rasa kulitnya lebih renyah dari chicken nugget.

\section{Warna}

Hasil uji organoleptik menyajikan bahwa rerata ranking kesukaan panelis terhadap warna dari kombinasi perlakuan antara Mush Nugget dengan So Good dan Charm berkisar antara 5,15 - 7,15 . Rerata ranking tingkat kesukaan panelis terhadap warna ditunjukkan pada Gambar 10.

Gambar 10 menyajikan rerata nilai kesukaan panelis terhadap warna pada berbagai merk nugget mempunyai nilai terendah sebesar 5,15 dari merk Charm. Sedangkan nilai tertinggi sebesar 7,15 didapatkan dari merk Mush Nugget. Kebanyakan panelis menyatakan warna Mush Nugget lebih menarik dari pada chicken nugget .

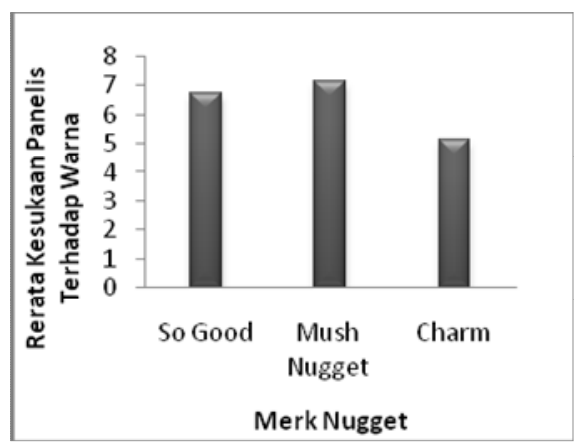

Gambar 10. Rerata Kesukaan Panelis terhadap Warna

\section{Aroma}

Hasil uji organoleptik menyajikan bahwa rerata ranking kesukaan panelis terhadap aroma dari kombinasi perlakuan antara Mush Nugget dengan So Good dan Charm berkisar antara 4,8 - 7,5. Rerata ranking tingkat kesukaan panelis terhadap aroma ditunjukkan pada Gambar 11.

Gambar 11 menyajikan rerata nilai kesukaan panelis terhadap aroma pada berbagai merk nugget mempunyai nilai terendah sebesar 4,8 dari merk Charm. Sedangkan nilai tertinggi sebesar 7,5 didapatkan dari merk So Good. Hal ini disebabkan karena kebanyakan panelis belum terbiasa dengan nugget beraroma jamur tiram putih dan ikan tongkol. 


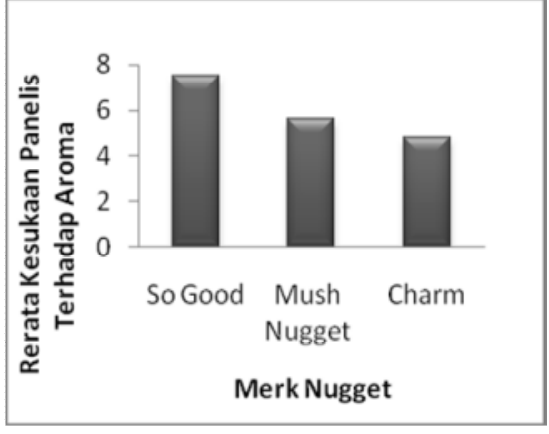

Gambar 11. Rerata Kesukaan Panelis terhadap Aroma

Penentuan perlakuan terbaik antara Mush Nugget dengan nugget So Good dan Charm menggunakan metode indeks efektivitas (Susrini, 2005). Metode ini dilakukan pada parameter organoleptik meliputi; aroma, warna dan rasa. Penilaian perlakuan terbaik disajikan pada Tabel 8.

Tabel 8. Perlakuan terbaik Uji Organoleptik dengan Produk Pasar

\begin{tabular}{|l|c|}
\hline \multicolumn{1}{|c|}{ Merk Nugget } & Nilai Produk \\
\hline So Good & 0,83 \\
\hline Mush Nugget & $\mathbf{0 , 8 5} *$ \\
\hline Charm & 0,00 \\
\hline
\end{tabular}

* = perlakuan terbaik

Tabel 8 menyajikan produk nugget terbaik diperoleh dari Mush Nugget dengan karakteristik sebagai berikut: rerata kesukaan panelis terhadap aroma 5,6; warna 7,15 dan rasa 7,2 .

Penelitian Tahap III: Scale up Pembuatan Nugget Jamur Tiram Putih

Penelitian Tahap III adalah pembuatan nugget jamur tiram putih dengan menaikkan skalanya menjadi $20 \quad \mathrm{~kg}$ berdasarkan perlakuan terbaik pada Tahap I.

Tabel 9 menyajikan kadar lemak, protein, karbohidrat mengalami penurunan. Hal ini disebabkan karena perbedaan tempat pembelian bahan baku jamur tiram (kualitas jamur tiram) dan perbedaan quantitas bahan baku maupun bahan pembantu. Mush Nugget mempunyai komposisi lemak yang sangat rendah yaitu, $0,43 \%$. Produk chicken nugget yang ada di pasaran seperti Charm mempunyai komposisi lemak sebesar 36\% dan So Good sebesar $10 \%$. Komposisi lemak yang sangat rendah tersebut, menjadikan produk Mush Nugget mempunyai keunggulan bila dibandingkan dengan produk chicken nugget yang ada di pasaran (Charm dan So Good). 
Tabel 9.Parameter Kimia sebelum dan sesudah dilakukan Scale up

\begin{tabular}{|l|c|c|}
\hline Parameter kimia & $\begin{array}{c}\text { Sebelum } \\
\text { Scale up }\end{array}$ & $\begin{array}{c}\text { Sesudah } \\
\text { Scale } \\
\text { up } \\
(\mathbf{2 0} \text { kg) }\end{array}$ \\
\hline Kadar Lemak (\%) & 0,69 & 0,43 \\
\hline Kadar Protein (\%) & 8,80 & 6,26 \\
\hline Kadar air (\%) & 64,41 & 67,45 \\
\hline $\begin{array}{l}\text { Kadar Karbohidrat } \\
\text { (\%) }\end{array}$ & 25,94 & 24,53 \\
\hline Kadar abu (\%) & 2,26 & 1,33 \\
\hline
\end{tabular}

Penelitian Tahap III: Kajian Kelayakan Finansial Produksi Nugget Jamur Tiram Putih Skala Industri Kecil

\section{Biaya Produksi}

Total biaya produksi selama 1 tahun nugget jamur tiram putih adalah sebesar Rp. 574.027.833,33 dengan perincian biaya tetap (fixed cost) sebesar Rp. 88.368.633,- dan biaya tidak tetap (variable cost) sebesar Rp. 485.659.200,- dengan produksi nugget jamur tiram putih rasa ikan tongkol sebanyak $105 \mathrm{~kg}$. Perhitungan biaya produksi dilakukan dalam periode 1 tahun yang merupakan jumlah keseluruhan dari biaya tetap dan biaya tidak tetap dalam 1 tahun yang melibatkan biaya bahan baku, biaya tenaga kerja dan biaya overhead pabrik (Husnan dan Sudarsono, 1999).

\section{Tenaga Kerja}

Tenaga kerja untuk unit usaha nugget jamur tiram putih rasa ikan tongkol skala industri kecil direncanakan sebanyak 8 orang yang terdiri dari 2 tenaga kerja tidak langsung yaitu, 1 manager dan 1 administrasi, serta 6 orang tenaga kerja langsung, 4 orang tenaga kerja proses produksi, 1 orang tenaga kerja penjualan dan promosi serta 1 orang sopir.

Tenaga kerja merupakan bagian dari keseluruhan proses produksi yang menjalankan setiap tahapan produksi. Tenaga kerja sebagian besar diperlukan untuk menangani proses pengolahan, selain itu diperlukan juga tenaga kerja yang menangani pengemasan.

Tenaga kerja yang bertugas untuk mengawasi jalannya mesin produksi sebelumnya telah diberi pengarahan dan pelatihan untuk penguasaan teknologi pengolahan produk nugget jamur tiram putih. Sehingga pelatihan yang diberikan diharapkan mampu menjalankan operasi produksi dengan baik. Begitu juga dengan tenaga kerja pada bagian pengemasan. 


\section{Harga Pokok Produksi (HPP)}

Harga Pokok Produksi (HPP) sebesar Rp. 5.695/250 g (Lampiran 24). Harga jual yang dihitung di tingkat produsen ke pengecer sebesar Rp. 8.542/250 g sampai dengan Rp. 8.600,00/250 g dengan asumsi pengambilan mark up sebesar $50 \%$ dari setiap produk unit yang terjual.

\section{Break Event Point (BEP)}

Hasil perhitungan

menyajikan bahwa titik balik pokok akan dicapai pada volume penjualan 23.729 unit atau senilai Rp. 202.697.442,09.

Apabila

perusahaan telah mencapai angka penjualan tersebut di atas, maka dapat diartikan bahwa perusahaan telah mencapai titik dimana perusahaan tidak mengalami kerugian maupun memperoleh keuntungan.

\section{Payback Periode (PP)}

Payback Periode merupakan metode yang digunakan untuk mengukur kecepatan pengembalian modal investasi yang dinyatakan dalam tahun. Hasil perhitungan menyajikan bahwa nilai payback period dicapai pada 2 tahun 8 bulan 23 hari.

\section{Net Present Value (NPV)}

Nilai Net Present Value (NPV) bernilai positif atau lebih besar dari nol, yaitu sebesar Rp. 180.633.576,Menurut Husnan dan Suwarso (2002), kriteria finansial bila NPV $>0$ maka proyek dinyatakan layak.

\section{Profitability Index (PI)}

Nilai Profitability Index (PI) bernilai positif atau lebih besar dari nol, yaitu sebesar 1,46. Menurut Husnan dan Suwarso (2002), proyek dinyatakan layak, apabila PI $>0$. Sedangkan unit usaha pengolahan nugget dari jamur tiram putih ini, mempunyai $\mathrm{PI}>0$, maka pengolahan ini layak dilaksanakan.

\section{KESIMPULAN DAN SARAN}

\section{Kesimpulan}

1. Perlakuan terbaik pada Tahap I berdasarkan indeks efektifitas diperoleh dari jamur tiram putih $100 \mathrm{~g}$, ikan tongkol $25 \mathrm{~g}$ dan tepung terigu $15 \mathrm{~g}$ dengan karakteristik sebagai berikut: kadar lemak 0,69\%; kadar protein $8,80 \%$; kadar air $64,41 \%$; kadar abu 2,26\%; kadar karbohidrat $25,94 \%$; rasa 6,12 ; warna 4,88; dan aroma 3,76.

2. Hasil analisa parameter kimia pada Tahap III setelah dilakukan scale up $20 \mathrm{~kg}$ didapatkan kadar 
lemak $0,43 \%$; kadar protein 6,26\%; kadar air 67,45\%; kadar karbohidrat 24,53\%; dan kadar abu $1,33 \%$.

3. Hasil Kelayakan finansial produk nugget jamur tiram putih rasa ikan tongkol didapatkan Harga Pokok Produksi (HPP) sebesar Rp. 5.695/250 g. Perhitungan BEP dicapai pada volume penjualan 23.729 unit atau senilai Rp. 202.697.442,09. Payback Period dicapai pada 2 tahun 8 bulan 23 hari. Nilai Net Present Value (NPV) sebesar Rp. 180.633.576,Profitability Index (PI) sebesar 1,46 dengan demikian unit usaha produksi nugget dari jamur tiram putih dengan tambahan ikan tongkol layak dilaksanakan.

\section{Saran}

Perlu dikaji penelitian lebih lanjut tentang lama penyimpanan nugget jamur tiram putih dengan ikan tongkol dan pembuatan nugget jamur tiram putih dengan berbagai jenis bahan tambahan (selain ikan tongkol), agar diperoleh nugget jamur tiram putih yang berkualitas layak secara teknis dan finansial.

\section{DAFTAR PUSTAKA}

Anonymous, 2002. Standar Nasional Indonesia (SNI) Naget ayam (chicken nugget).

http://www.bsn.go.id/. Diakses tanggal 6 Juni 2010 2008

Pengolahan Jamur. Tekno Pangan dan Agroindustri, volume 1 no.7.

http://www.google.co.id/. Diakses tanggal 12 Agustus 2009 2009. Jamur Tiram http://id.wikipedia.org/wiki/Jamur tiram. Diakses 12 Agustus 2009. http://id.wikipedia.org/w/index.ph $\mathrm{p}$ ?title $=$ Terigu \& redirect $=$ no.

Diakses tanggal 25 Agustus 2009. 2010. Komposisi Tepung

Terigu.

http://makara393.blogspot.com/20

10/01/komposisi-tepung-

terigu.html. Diakses tanggal 31 Januari 2010 , 2010. Khasiat Daging Ikan Tongkol. http://2.bp.blogspot.com/ JXduGI D8vWg/S1TcGiw9EbI/AAAAAA AAAqo/PBCXXhAyjGc/s1600h/IkanTongkol\%282\%29.htm. Diakses tanggal 1 Juni 2010.

Bobek, P., Ozdin, O. \& Mikus, M. 1995 Dietary oyster mushroom (Pleurotus ostreatus) accelerates plasma cholesterol turnover in hypercholesterolaemic rats. Physiological Research 44, 287291. http://www.springerlink.com/. Diakses tanggal 24 Agustus 2009

Bobek, P., Ozdin, L. \& Galbavy, S. 1998 Dose- and time-dependent 
hypercholesterolaemic effect of oyster mushroom (Pleurotus ostreatus) in rats. Nutrition 14, 282-286.

http://www.springerlink.com/.

Diakses tanggal 24 Agustus 2009

Connel, J.J., 1980. Control Fish Quality. Second Edition. Fishing News Book Ltd

Francis, F.J. 2000. "Starch" dalam Willey Encyclopedia of Food Science and Technology. John Willey and Sons, Inc. New York. 2203-2209.

http://www.google.co.id/. Diakses tanggal 30 Oktober 2009

Husnan, S. Dan Suwarsono. 2002

Studi Kelayakan Proyek. Edisi

Ketiga. Penerbit UPP AMP YKPN.

Yogyakarta.

Joshita.D, Juheini, 2009. Teknologi

Kosmetik. Farmasi Universitas

Indonesia.

Http://Www.Google.Co.Id/.

Diakses Tanggal 27 Desember 2009.

Labuza, T.P., 1982. Shelf-life Dating of Foods Westport, Connecticut 06880 USA : Food and Nutrition Press. Inc. http://www.google.co.id/. Diakses tanggal 27 Agustus 2009.

Leksono, T dan Syahrul, 2001. Studi Mutu Dan Penerimaan Konsumen Terhadap Abon Ikan. Jurnal Natur Indonesia III $\begin{array}{llll}\text { (2): } \quad 178- & 184 & \text { (2001). }\end{array}$ http://www.google.co.id/. Diakses tanggal 1 Juni 2010.
Nitisemito, A.S. 1998. Pengantar Praktis Ekonomi Perusahaan : Pedoman Mendirikan dan Membina Usaha. Penerbit Ghalia Indonesia, Jakarta

Obodai, M. J. Cleland-Okine. K.A. Vowotor, 2003. Comparative study on the growth and yield of Pleurotus ostreatus mushroom on different lignocellulosic byproducts. J Ind Microbiol

Biotechnol (2003) 30: 146-149 DOI 10.1007/s10295-002-0021-1. http://www.springerlink.com. Diakses tanggal 24 Agustus 2009. Rahmana, A., 2009. Peranan Teknologi Informasi Dalam Peningkatan Daya Saing Usaha Kecil Menengah. Seminar Nasional Aplikasi Teknologi Informasi 2009 (SNATI 2009) Yogyakarta, 20 Juni 200. ISSN: 1907-5022. http://www.google.co.id/. Diakses tanggal 9 Desember 2009.

Richana, N., P. Lestari, N. Chilmijati, dan S. Widowati. 1999. Karakterisasi bahan berpati (tapioka, garut, dan sagu) dan pemanfaatannya menjadi glukosa cair. Prosiding PATPI. http://www.google.co.id/. Diakses tanggal 25 Agustus 2009

Satriyanto F,2009, Jamur Tiram Putih.

http://jamursekolahdolan.blogspot. com/. Diakses tanggal 19 Januari 2010

Sudarmaji, S., Horyono B.S dan Suhardi. 1989. Analisa Bahan 
Makanan dan Pertanian.

Yogyakarta : PAU Pangan \& Gizi, UGM.

Siswono, 2002. Jamur Tiram untuk Antikolesterol.

http://www.gizi.net/ index.shtml. Diakses tanggal 27 Agustus 2009

Suharyono As., Susilawati, 2006. Pengaruh Jenis Tempe Dan Bahan Pengikat Terhadap Sifat Kimia Dan Organoleptik Produk Nugget Tempe. Prosiding Seminar Hasil-hasil Penelitian \& Pengabdian Kepada Masyarakat 2006.

Sutojo, S. 1999. Studi Kelayakan Proyek ; Teori dan Praktek. PT Pustaka Binaman Pressindo, Jakarta.

Susrini. 2005. Index Efektifitas;

Suatu Pemikiran Tentang Alternatif untuk Memilih Perlakuan Terbaik pada Penenlitian Pangan. Edisi Ketiga dengan Perbaikan. Program Studi Teknologi Hasil Ternak. Fakultas Peternakan. Universitas Brawijaya. Malang.

Syartiwidya, 2003. Kajian Tekstur dan Perubahan Mikrostruktur Nugget Ikan Selama Pengolahan dan Penyimpanan. http://www.google.co.id/. Diakses tanggal 31 Januari 2010.

Suzuki, T. 1981. Fish Krill Protein Procesing Technology. Aplied Science Publisher, Ltd. London. http://www.google.co.id/. Diakses tanggal 30 Oktober 2009

Tanikawa, 1998. Fermented Foods. J. Food Tech. 26:12-16. http://www.google.co.id/. Diakses tanggal 12 Agustus 2009

Umar, H. 2000. Studi Kelayakan Bisnis: Manajemen, Metode, dan Kasus. Penerbit PT Gramedia Pustaka Utama, Jakarta. Utomo, A.R, Ristiarini, S., Reynaldo, SR., 2004. Penentuan Kombinasi Terbaik Penambahan Maltodekstrin De12 Dan Stpp Pada Pengolahan Surimi Ikan Tonglol (Euthynnus Affinis). Seminar Nasional dan Kongres

Perhimpunan Ahli Teknologi Pangan Indonesia (PATPI). http://www.google.co.id/. Diakses tanggal 1 Juni 2010. 